\title{
Deep subsurface temperatures in the Roer Valley Graben and the Peelblock, the Netherlands - new results
}

\author{
R.T. Van Balen', J.M. Verweij, J.D. van Wees, H. Simmelink, F. Van Bergen \\ \& H. Pagnier
}

Netherlands Insititute of Applied Geoscience TNO - National Geological Survey, Department of Geo-Energy, P.O. Box 80015, 3508 TA Utrecht, The Netherlands

1 corresponding author, now at the Faculty Earth and Life Sciences, Vrije Universiteit, De Boelelaan 1085, 1081 HV Amsterdam, the Netherlands; e-mail: balr@geo.vu.nl

Manuscript received: February 2001; accepted October 2001

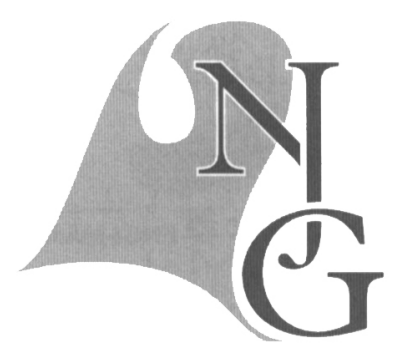

\begin{abstract}
The deep subsurface temperature data of the Roer Valley Graben have been re-analysed and combined with new temperature data from hydrocarbon exploration wells. The results show that the deep subsurface temperature distribution in the Roer Valley Graben is essentially the same as in the relatively stable high bordering the Roer Valley Graben to the southwest. Thus, the Cenozoic tectonic evolution of the Roer Valley Graben, which is characterized by uplift and denudation during the Late Eocene and subsidence due to rifting starting from Late Oligocene, has hardly affected the temperatures in the graben, which is probably due to the slow subsidence and sedimentation rates. In contrast to what is suggested on previously published temperature maps, the RoerValley Graben is probably not a relatively cold area in the Netherlands.
\end{abstract}

Keywords: Roer Valley Graben, The Netherlands, subsurface temperature, drill stem test, bottom hole temperature, Horner correction, RFT temperature

\section{Introduction}

The Roer Valley Graben is located in the southeastern part of the Netherlands and the adjacent parts of Belgium and Germany (Fig. 1). The Cenozoic Roer Valley Graben is part of the northwestern branch of the Rhine Graben rift system (Ziegler, 1990). To the northeast, the Roer Valley Graben is separated from the Peel Block/Maasbommel High by a major fault zone, the Peel Boundary Fault, and to the southwest a number of down stepping faults delineate the boundary with the Paleozoic Brabant Massif. To the west, the Roer Valley Graben is bordered by the West Netherlands Basin, which has a similar Late Paleozoic and Mesozoic evolution (e.g. Van Balen et al., 2000). The Cenozoic Roer Valley Graben developed upon pre-existing basins of Carboniferous and TriassicJurassic age. It is structurally closely related to the
Late Jurassic basin and to the area affected by inversion tectonics during the Late Cretaceous (Geluk et al., 1994; Gras \& Geluk, 1999). During the Neogene the basin development is mainly characterized by subsidence due to rifting, punctuated by phases of uplift and erosion (Geluk et al., 1994; Houtgast \& Van Balen, 2000).

The existing regional studies for the deep part of the Dutch subsurface (Visser, 1978; Prins, 1980; Ramaekers, 1991) indicate that the central part of the Roer Valley Graben is a relatively cold area, with temperatures $15 \%$ lower than average (see below). In this study, data from coal, hydrocarbon (oil and gas) and geothermal exploration from Belgian, German and Dutch territories are combined to assess a more detailed structure of the deep subsurface temperature field, which will be used in future basin modelling and geothermal studies. Part of the data have been 


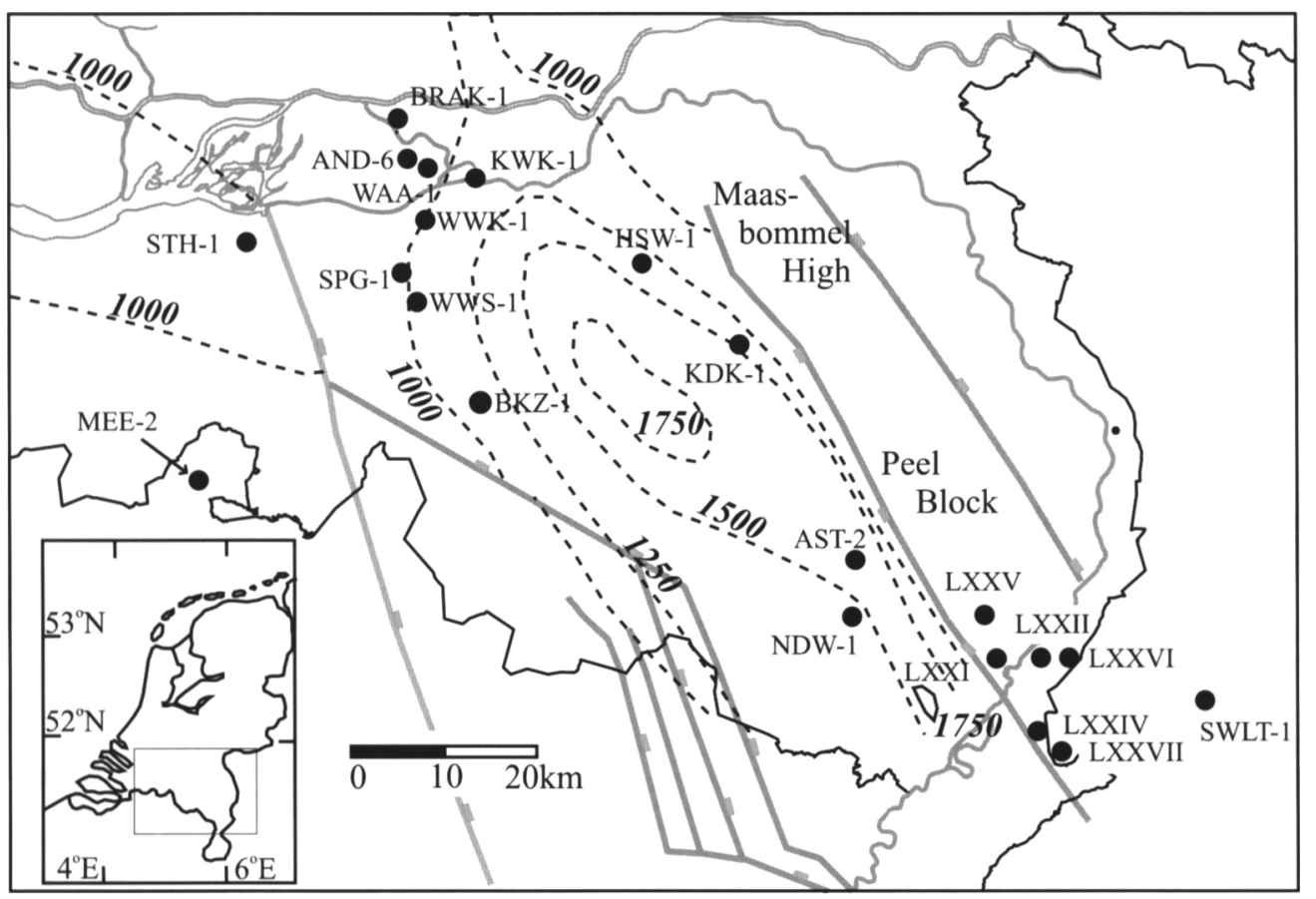

Fig. 1. Location map of the study area. The schematic fault pattern is after Geluk et al. (1994).

The dashed lines represent contours of the thicknesses of the Cenozoic deposits (modified after Geluk, 1990).

published before (e.g. Visser, 1978; Ramaekers, 1991). But, these older data have been reprocessed together with the new data from hydrocarbon exploration in order to arrive at a consistently corrected temperature data set.

\section{Previous results}

The earliest known subsurface temperature data in the Netherlands were obtained in 1879 in a $365 \mathrm{~m}$ deep groundwater exploration borehole in the central part of the country (Visser, 1978). During the 1910's and 1950's new data were gathered in coal exploration wells in the southern and eastern parts of the Netherlands (see also below). Starting in the 1950's, temperature measurements were carried out in oil and gas exploration wells, located mainly in the western-, northern-, and offshore parts of the Netherlands.

\section{Hydrocarbon exploration data}

Based on oil and gas exploration data, the first deep subsurface temperature map for the Netherlands was published by Prins (1980). An update of this temperature map was published by Ramaekers (1991). The latter publication is based on a much larger dataset and contains maps for several depth intervals, including a surface heat flow map. The maps are based on 130 offshore wells and 334 onshore wells. The offshore data were obtained from Robertson Group PLC (Haile et al., 1987) and consist of drill stem test (DST) temperature data and corrected bottom hole temperatures (BHT's). For 53 onshore wells the BHT measurements were corrected using a Hornertype extrapolation method (see below). An empirical BHT to true temperature correction formula obtained from these results was used to convert the remaining BHT data for which no Horner-type correction could be made due to lack of data. A uniform thermal conductivity for each chrono-lithostratigraphic unit and steady-state thermal conditions were assumed during the construction of the maps. Both assumptions are large simplifications: Lithology and porosity are the main factors that control thermal conductivity, not the age of the deposits. Secondly, due to the climate changes and tectonic activity in the Dutch subsurface during Cenozoic times, and related changes in sedimentation, erosion and groundwater flow, the subsurface temperature distribution can not be in a steady-state situation. In particular the southeastern part of the Netherlands is affected by Recent tectonic activity.

According to Rijkers \& Van Doorn (1997), the subsurface temperature maps (Fig. 2) show that the thermal structure of the subsurface closely corresponds to the outlines of structural units of Late Jurassic to Early Cretaceous age, with platform areas and structural highs characterized by relatively cold temperatures and basins by relatively higher than average temperatures (Fig. 2). Exceptions to this trend are the relatively cold Roer Valley Graben with temperatures about $15 \%$ lower than average, and the relatively warm Peel Block/Maasbommel High to the northeast of the graben, characterized by $10 \%$ higher than average temperatures. The mean heatflow in the Nether- 


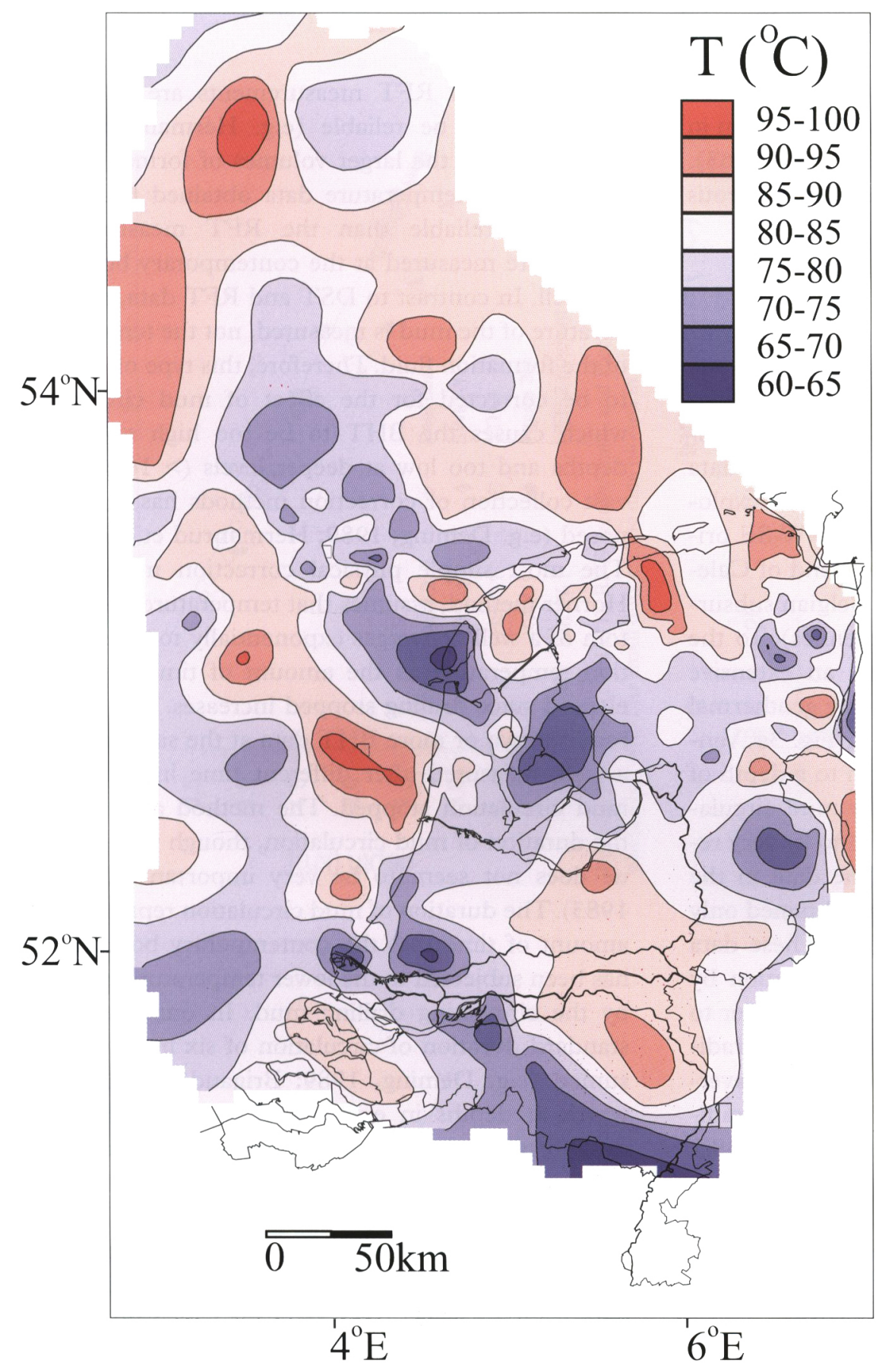

Fig. 2. The temperature distribution at 2000 $m$ depth in the Netherlands (modified after Rijkers \& Van Doorn, 1997).

In the southeastern part this map is not correct. See text for discussion.

lands equals about $76 \mathrm{~mW} / \mathrm{m}^{2}$ and the average geothermal gradient at the $0.5-3 \mathrm{~km}$ depth interval is about $33^{\circ} \mathrm{C} / \mathrm{km}$ (Ramaekers, 1991).

\section{Additional Dutch data}

Data of the geothermal well AST-2, located in the eastern part of the Roer Valley Graben, show an average temperature gradient of $32^{\circ} \mathrm{C} / \mathrm{km}$ down to a depth of about $1650 \mathrm{~m}$ (Fig. 1, Fig. 3b; Heederik et al., 1989). In detail, the geothermal gradient varies with depth. From 830 to $1093 \mathrm{~m}$ the gradient equals $33^{\circ} \mathrm{C} / \mathrm{km}$; it increases to a value $39^{\circ} \mathrm{C} / \mathrm{km}$ between
1196 and $1415 \mathrm{~m}$ depth, and then decreases to a value of $23^{\circ} \mathrm{C} / \mathrm{km}$ from 1494 to $1530 \mathrm{~m}$ depth (Heederik et al., 1989). The upper part of the well $(0-830 \mathrm{~m})$ has a temperature gradient similar to the $830-1093 \mathrm{~m}$ depth interval. The data from AST-2 were collected two months after drilling the well and are considered to be very reliable.

On behalf of coal exploration on the southeastern part of the Peel Block, a few 'very accurate' temperature measurements were collected in six DSM wells (LXXI, LXXII, LXXIV, LXXV, LXXVI and LXXVII), down to a depth of about $1350 \mathrm{~m}$ (Figs. 1, 3b; Peelcommissie, 1963). Details of the measure- 
ments are given by Visser (1978). The temperatures found in these wells typically show a gradient in the Quaternary and Tertiary sediments of 21.4 to 29 ${ }^{\circ} \mathrm{C} / \mathrm{km}$ and a higher gradient of 37.3 to $45.5^{\circ} \mathrm{C} / \mathrm{km}$ in the underlying Carboniferous (Peelcommissie, 1963). On average the depth to the top of the Carboniferous strata in these wells is about $650 \mathrm{~m}$.

\section{Belgian temperature data}

Subsurface temperature maps and temperature data for the Belgian part of the Roer Valley Graben are given by Vandenberghe \& Fock (1989) and Vandenberghe et al. (1988). The maps are based on data from geothermal energy, coal and hydrocarbon exploration. The maps show a relatively cool, NW-SE oriented central area, coinciding with the trend of Caledonian and Variscan structures in the Belgian subsurface (the Brabant Massif and the Ardennes). To the southwest of the Roer Valley Graben an extensive temperature dataset was collected during geothermal exploration in the well MEE-2 (Fig. 1, Fig. 3a; Vandenberghe et al., 1988). The data down to a depth of $1699 \mathrm{~m}$ were collected 4 months after mud circulation stopped. These data are considered to be very reliable (Vandenberghe et al., 1988). The data in the depth range from 1700 to $2230 \mathrm{~m}$ were obtained only 10 hours after mud circulation stopped. These data were corrected for the effect of mud circulation by shifting the temperatures to higher values in order to fit to the shallower data. The observed thermal gradient in the Tertiary succession (100-808 m) is on average $29^{\circ} \mathrm{C} / \mathrm{km}$ (Vandenberghe et al., 1988). The gradient increases downward in the well to a value of 38.2 ${ }^{\circ} \mathrm{C} / \mathrm{km}$ in the Upper Carboniferous section (11862234). An average gradient of $35.21^{\circ} \mathrm{C} / \mathrm{km}$ is determined by linear regression of the dataset.

\section{New deep subsurface temperature results}

The data gathered from 23 exploration wells in the Roer Valley Graben, including the well SWLT-1 in Germany, consist of 4 drillstem test (DST) temperature measurements in the well NDW-1, 6 temperature data sets from repeat formation tests (RFT) in the wells AND-6, BKZ-1, BRAK-1, HSW-1 and $\mathrm{KWK}-1$, and a suite of bottomhole temperature (BHT) data from all 23 wells. In addition, the well $\mathrm{BKZ}-1$ has a continuous temperature $\log$ based on the temperature of outflowing mud. Due to the uncertainty associated with this type of data, this dataset has not been used. The location of the wells is indicated in Fig. 1.

\section{Data quality and correction}

The DST and RFT measurements are in general considered to be reliable (e.g. Hermanrud et al., 1991). Due to the larger volumes of formation fluid involved, the temperature data obtained from DST are more reliable than the RFT measurements. BHT's are measured at the contemporary bottom of the well. In contrast to DST and RFT data, the temperature of the mud is measured, not the temperature of the formation fluid. Therefore, this type of data has to be corrected for the effect of mud circulation, which causes the BHT to be too high at shallow depths and too low at deeper levels $(>1000 \mathrm{~m})$. A vast collection of correction methods has been proposed (e.g. Deming, 1989; Hermanrud et al., 1990). The most simple physical correction method, the Horner method, assumes that temperature at the bottom of a well converges exponentially to true formation temperature as the amount of time which has elapsed since drilling stopped increases. The method requires two or more $\mathrm{BHT}$ data at the same depth in a well, measured after different time intervals after mud circulation stopped. The method also requires the duration of mud circulation, though its exact value does not seem to be very important (Luheshi, 1983). The duration of mud circulation represents the amount of time that the contemporary bottom hole has been subjected to the lower temperatures induced by the circulating drilling mud. In our analyses, a standard duration of circulation of six hours was assumed (e.g. Deming, 1989; Brigaud et al., 1992), which at depths in excess of $2500 \mathrm{~m}$ corresponds roughly to the time needed for the last three meters of drilling. For comparison, a duration of circulation of only two hours was applied to one dataset; it resulted in less than $1 \%$ difference in estimated temperature. In this study the Horner method could be applied to data from 12 wells. BHT data for which no Horner method could be applied were disregarded. The total dataset on which this study is based is thus limited to 13 of the 23 considered exploration wells.

\section{Results}

In Fig. $3 b$ and $3 c$ the DST, RFT and corrected BHT data are plotted per well, in addition to the temperature dataset from the geothermal exploration well AST-2 and the coal exploration data from the southeastern part of the Peel Block. The same data are plotted per measurement type in Fig. 3d. The straight line in these figures represents the gradient obtained by linear regression of the MEE-2 dataset (Fig. 3a). Based on these plots, we conclude that the data from 

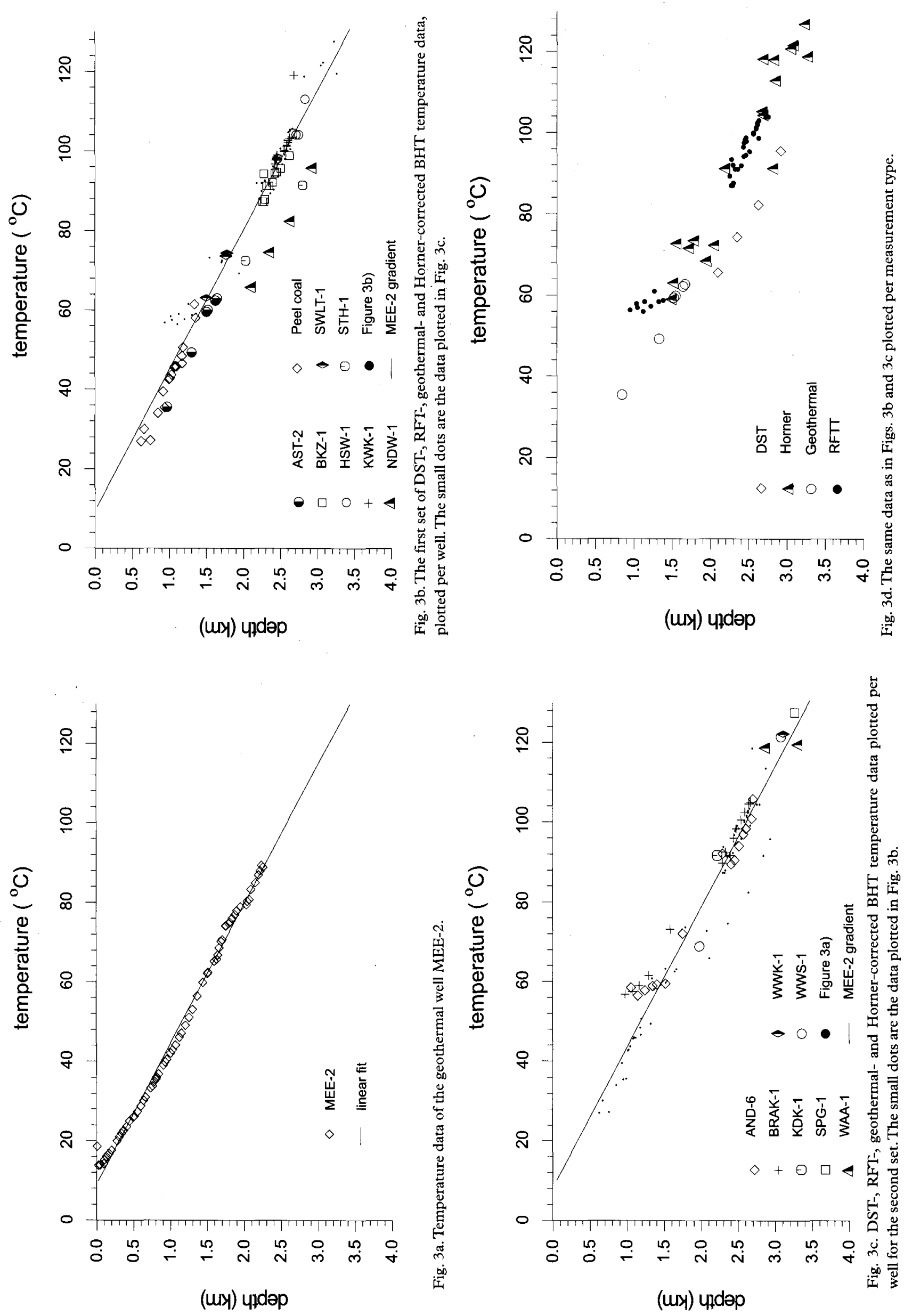

Netherlands Journal of Geosciences / Geologie en Mijnbouw 81(1) 2002 
the Roer Valley Graben are in line with the data from MEE-2, especially the data obtained from the deep RFT measurements. The shallow $(<2 \mathrm{~km})$ RFT temperature data and their gradients for the wells AND-6 and BRAK-1 are anomalously high. An explanation for this deviation is that these data were probably collected shortly after completion of the well; circulating drilling mud and cement hardening may have caused a heating of the wall of the undeep part of the well. The scattering of the corrected BHT data around the average gradient can be explained by the uncertainty associated with BHT data in general and, in addition, by the simple correction method that we have applied. The DST temperature data from NDW-1 are about $15^{\circ} \mathrm{C}$ less than average. They are discussed below.

\section{Discussion and conclusions}

The Roer Valley Graben has been tectonically active during the Cenozoic. Two important tectonic phases are recognized: a Late Eocene uplift and erosion phase, and a rifting phase which starts in the Late Oligocene and continues until Present-day (Geluk, 1990; Geluk et al., 1994; Houtgast \& Van Balen, 2000). The tectonic events have probably affected the deep subsurface temperature field by processes like uplift, subsidence, sedimentation, erosion and groundwater flow. However, the bulk Present-day deep subsurface temperature data of the Roer Valley Graben show minor differences with the general trend from the data of the well MEE-2, located on the high bounding the Roer Valley Graben to the southwest. This high was affected by the regional Late Eocene uplift, but not by the Late Oligocene rifting.

The main exceptions to the general temperature trend are the DST data from NDW-1, which are systematically about $15^{\circ} \mathrm{C}$ lower than average. This can not be explained by a tectonic mechanism acting during the Late Eocene uplift or Late Oligocene-Recent rifting. Results from apatite fission-track analyses (Table 1; Clyde Petroleum Exploration, 1992) show that the denudation during the Late Eocene uplift re-

Table 1. Results from fission-track analyses.

\begin{tabular}{lllll}
\hline & NDW-1 & BKZ-1 & KDK-1 & HSW-1 \\
\hline Level & $\begin{array}{l}\text { Carboni- } \\
\text { ferous }\end{array}$ & Triassic & Triassic & Triassic \\
Cooling & $>22^{\circ} \mathrm{C}$ & $14-19^{\circ} \mathrm{C}$ & $8-13^{\circ} \mathrm{C}$ & $5^{\circ} \mathrm{C}$ \\
Interval & $80-50 \mathrm{Ma}$ & $60-20 \mathrm{Ma}$ & $60-40 \mathrm{Ma}$ & $60-0 \mathrm{Ma}$
\end{tabular}

level = stratigraphic level of the samples, cooling $=$ amount of cooling of the sample, interval = time interval during which cooling has taken place. sulted in a significant absolute cooling of the rocks in the wells BKZ-1 and HSW-1. The cooling event documented by fission-track data of the wells KDK-1 and NDW-1 is older. But, because the thermal evolution history, which has been used to model the fission-track data is not in accordance with the uplift and subsidence history which can be derived from the sedimentary record in these wells, the thermal event is badly constrained. An improved thermal evolution model would probably yield a Late Eocene age for cooling event in these wells too. As a result of the Late Eocene uplift, the temperature-depth trends, i.e. temperatures in the wells, were elevated due to the combination of uplift and denudation. Therefore, prior to the Late Oligocene-Recent rifting phase, the subsurface temperatures in the Roer Valley Graben were elevated. The magnitude of the Late Eocene thermal event increased from north to south in the Roer Valley Graben, and correspondingly the amount of uplift and denudation. If a thermal effect of the Late Eocene event would still exist at NDW-1, it would have to be a positive anomaly. During the Late Oligocene-Recent rifting period, the thermal evolution of the Roer Valley Graben was affected by subsidence and a process called thermal blanketing (e.g. Ter Voorde, 1996). However, since the rate of subsidence is more than one thousand times smaller than the rate of conduction, thermal conduction will have kept up with subsidence, nullifying a thermal effect. The thermal blanketing process is a result of the relatively high porosity and, therefore, low conductivity of fresh deposited sediments. As a result of the low conductivity the surface heatflow is reduced, which has a warming effect on the underlying sediments. An effective increase of conductivity by thermal convection of pore fluids is excluded by the presence of sequences of low permeable deposits in the Neogene fill of the Roer Valley Graben. Therefore, based on the thermal blanketing mechanism, deep subsurface temperatures in the Roer Valley Graben are expected to be higher than average at positions where the Cenozoic succession reaches its maximum thickness, for example at the location of NDW-1 (Fig. 1). This is not in accordance with the DST temperature data.

Local downward directed groundwater flow is another potential explanation for the deviation of the NDW-1 temperature data. At present, the fresh-salt water interface, defined by the $150 \mathrm{mg} / \mathrm{l}$ chloride concentration, is at a depth of $320 \mathrm{~m}$ in the geothermal well AST-2 (Fig. 1), nearby NDW-1. The chloride concentration profile in this well indicates that in the recent past freshwater has infiltrated down to at least the bottom of the well $(1639 \mathrm{~m}$; Heederik et al., 1989). This meteoric water can have infiltrated by lat- 
eral (from the surrounding highs) and by downward (vertical) groundwater flow. As pointed out by Deming (1994), the effect of groundwaterflow on the temperature distribution depends on the flow rate, which is determined by the permeability. At average permeabilites of the order of $10^{-17} \mathrm{~m}^{2}$ and lower, vertical fluid flow fails to affect the temperature distribution significantly (Deming, 1994). In case of NDW-1, the downward flow would have to cross Lower Jurassic and Upper Triassic layers, comprising several claystone intervals with a total thickness of $174 \mathrm{~m}$ and an evaporite interval of $19 \mathrm{~m}$ thickness. These lithologies are in general characterized by very low permeabilities, lower then $10^{-17} \mathrm{~m}^{2}$, making thermal effects of vertical groundwater flow down to a depth of $2.5 \mathrm{~km}$ unlikely.

Therefore, we conclude that the DST temperature data of NDW-1 are probably affected by a measurement error. The fact that the gradient in NDW-1 is equal to the gradient of the bulk data could indicate that the DST tool was not correctly calibrated. It should be mentioned that the well is relatively old, dating from 1965. The temperature distributions in the central part of the Roer Valley Graben as shown on the maps published by Ramaekers (1991) are dominated by the data from NDW-1. Therefore, these maps should be carefully interpreted. In addition, the interpolation of temperature data of these maps is based on steady-state thermal conditions and uniform thermal conductivities. Such simplifications may lead to serious errors. Thus, the Roer Valley Graben is probably not a relatively cold area in the Netherlands, which is in agreement with shallow mantle temperatures beneath the graben derived by Goes et al. (2000).

In detail, the data of the coal exploration wells and the geothermal well AST-2 show changes in the temperature gradient with depth (Fig. 3b,c). These changes can be attributed to variations in the thermal conductivity of the sediments (e.g. Visser, 1978). In addition, minor effects of groundwater flow and variations in surface temperature due to climate changes during the Quaternary might have some effects on the present-day temperature distribution in these relatively shallow wells.

\section{Acknowledgements}

The authors want to thank Mark Geluk, Cees de Leeuw, Jo Ramaekers, Joost Verbeek, Nora Witmans (TNO-NITG) and Marlies Ter Voorde (Vrije Universiteit, Amsterdam) for discussions. The Nederlandse Aardolie Maatschappij (NAM) and Clyde Petroleum Exploration B.V. are thanked for permission to use their data. The paper greatly benefitted from reviews by Noel Vandenberghe and Jo Ramaekers.

\section{References}

Brigaud, F., Vasseur, G. \& Caillet. G., 1992. Thermal state in the north Viking Graben (North Sea) determined from oil exploration well data. Geophysiscs 57: 69-88.

Clyde Petroleum Exploration, 1992. Thermal history reconstructions in onshore wells using apatite fission track analysis and vitrinite reflectance. Internal report prepared by Geotrack International Pty Ltd, report n. 407.

Deming, D., 1989. Application of bottom-hole temperature corrections in geothermal studies. Geothermics 53: 979-988.

Deming, D., 1994. Fluid flow and heat transport in the upper continental crust. In: Parnell, J. (ed.): Geofluids: Origin, Migration and Evolution of Fluids in Sedimentary Basins. Geological Society Special Publication 78: 27-42.

Geluk, M.C., 1990. The Cenozoic Roer Valley Graben, Southern Netherlands. Mededelingen Rijks Geologische Dienst 44: 66-72.

Geluk, M.C., Duin, E.J.Th., Dusar, M., Rijkers, R.H.B., Van den Berg, M.W. \& Van Rooijen, P., 1994. Stratigraphy and tectonics of the Roer Valley Graben. Geologie en Mijnbouw 73: 129-141.

Goes, S., Govers, R. \& Vacher, P., 2000. Shallow mantle temperatures under Europe from $\mathrm{P}$ and $\mathrm{S}$ wave tomography. Journal of Geophysical Research 105: 11153-11169.

Gras, R. \& Geluk, M., 1999. Late Cretaceous and Early Tertiary sedimentation and tectonic inversion in the southern Netherlands. Geologie en Mijnbouw 78: 1-19.

Haile, N.S., Flavell, W.S. \& Gorst, M., 1987. Geothermal database North Sea. Robertson Research International Ltd.

Heederik, J.P., Brugge, J., Bremmer, C.H., Coenegracht, Y.M.A., Van Doorn, T.H.M. Huurdeman, A.J.M., Van Gaans, P.F.M., Vasak, L.,Vierhout, R.M. \& Zuurdeeg, B.W., 1989. Geothermische reserves centrale slenk, Nederland. Exploratie en evaluatie. Internal report OS 89-18TNO GG, Delft.

Hermanrud, C., Cao, S. \& Lerche, I., 1990. Estimates of virgin rock temperatures from well-logs-accuracy analysis of some advanced inversion models. Marine and Petroleum Geology 6: 360-363.

Houtgast, R. \& Van Balen, R.T., 2000. Neotectonic evolution of the Roer Valley Graben. Global and Planetary Change 27: 147164

Luheshi, M.N., 1983. Estimation of formation temperature from borehole measurements. Geophysical Journal of the Royal Astronomical Society 74: 747-776.

Peelcommissie, 1963. Rapport van de Peelcommissie, SDU, 's Gravenhage, pp. 133.

Prins, S., 1980. The Netherlands. In: R. Haenel (ed.): Atlas of subsurface temperatures in the European Community. Commission of the European communities. Th. Schaefer GmbH, Hannover, pp. 36.

Ramaekers, J.J.F., 1991. The Netherlands. In: Hurtig, E., Čermak, V. Haenel, R. \& Zui, V. (eds.): Geothermal Atlas of Europe. Hermann Haack Verlagsgesellschaft mbH, Gotha.

Rijkers, R. \& Van Doorn, Th.H.M., 1997. Atlas of geothermal resources in the European Community, the Netherlands. NITGTNO report 97-24-A, Delft.

Ter Voorde, M., 1996. Tectonic modelling of lithospere extension along faults, implications for the thermal and mechanical structure and basin stratigraphy. $\mathrm{PhD}$ thesis Vrije Universiteit, Amsterdam, pp. 197.

Van Balen, R.T., Van Bergen, F., De Leeuw, C., Pagnier, H., Simmelink, H., Van Wees, J.D. \& Verweij, J.M. 2000. Modelling the 
hydrocarbon generation and migration in the West Netherlands Basin, the Netherlands. Geologie en Mijnbouw/Netherlands Journal of Geosciences 79: 29-44.

Vandenberghe, N., Dusar, M., Laga, P. \& Bouckaert, J., 1988. The Meer well in North Belgium, Toelichtende Verhandelingen voor de Geologische en Mijnkaarten van België, 25, Belgische Geologische Dienst, Brussel, pp. 23.
Vandenberghe, N. \& Fock, W., 1989. Temperature data in the subsurface of Belgium. Tectonophysics 164: 237-250.

Visser, W.A., 1978. Early subsurface temperature measurements in the Netherlands. Geologie en Mijnbouw 57: 1-10.

Ziegler, P., 1990. Geological Atlas of Western and Central Europe, second edition, Shell Internationale Petroleum Maatschappij, The Hague, 239 pp. 